\title{
MENGGALI PELUANG EKONOMI KREATIF MELALUI POTENSI DESA SUKA MAJU KABUPATEN BENGKAYANG
}

\author{
Benedhikta Kikky Vuspitasari ${ }^{(1)}$, Deffrinica ${ }^{(2)}$, dan Shanti Veronnica Br Siahaan ${ }^{(3)}$ \\ ${ }^{1,3}$ Program Studi Kewirausahaan Institut Shanti Bhuana \\ ${ }^{2}$ Program Studi Manajemen Institut Shanti Bhuana \\ ${ }_{1,2,3}$ Bengkayang 79211 Kalimantan Barat \\ E-mail : kikky@ shantibhuana.ac.id ${ }^{1)}$, deffrinica@ shantibhuana.ac.id ${ }^{2)}$, siahaan.shanti@ shantibhuana.ac.id ${ }^{3)}$
}

\begin{abstract}
ABSTRAK
Pelaku ekonomi kreatif Kabupaten Bengkayang sebesar $0.74 \%$ artinya masih rendahnya ekonomi kreatif dan banyak potensi yang belum dimaksimalkan Jika dilihat potensi-potensi yang ada di desa Suka Maju, sektor pertanian merupakan salah satu sektor yang menopang perekonomian di daerah tersebut namun belum dioptimalkan dengan baik apakah ada peluang ekonomi lainnya. Tujuan penelitian ini untuk mengidentifikasi apa saja potensi desa yang dapat menjadi peluang ekonomi kreatif di Desa Suka Maju dan Faktor apa saja yang menjadi penghambat peluang ekonomi kreatif di Desa Suka Maju. Penelitian ini metode kualitatif pendekatan Studi Kasus, fokus pada masyarakat Desa Suka Maju, data primer perangkat desa dan masyarakat Desa. Teknik Pengumpulan Data menggunakan teknik observasi, wawancara mendalam, studi dokumentasi. Validitas data menggunakan metode triangulasi. Ada tiga tahapan analisis dalam penelitian yaitu, eksplorasi, interpretasi, kontekstualisasi, hasil penelitian potensi desa Suka Maju berkaitan dengan hasil pertanian dan perkebunan dimana masyarakat lebih banyak mengolah lahan untuk menanam padi di sawah maupun di ladang, selain itu jagung, karet, buah kenari, emas, karet dan sawit yang menjadi potensi ekonomi kreatif adalah anyaman bambu dan wisata alam. Kurangnya pengetahuan berkaitan dengan rendahnya sumber daya manusia, kurangnya kesadaran memanfaatkan potensi desa, Masyarakat terbiasa melakukan semua hal namun tidak difokuskan, kurangnya peran desa dalam membina penganyam bambu, Kurangnya modal menjadi faktor penghambat.
\end{abstract}

Kata Kunci: Peluang Ekonomi Kreatif, Potensi Desa

\section{PENDAHULUAN}

Saat ini ekonomi kreatif menjadi salah satu sektor yang dapat membantu meningkatkan ekonomi nasional, terbukti bahwa sektor ekonomi kreatif menjadi salah satu sektor yang penyumbang PDB di Indonesia pada tahun 2019 artinya bahwa masyarakat Indonesia merupakan masyarakat yang sadar akan banyaknya potensi alam yang dapat diolah dan manfaatkan melalui kreativitas yang dimiliki, pemanfaatan Potensi yang ada melalui peningkatan ekonomi kreatif, menurut (Purnomo, 2016) ekonomi kreatif merupakan salah satu konsep ekonomi yang dapat direalisasikan secara berkelanjutan dengan memanfaatkan kreativitas yang dimiliki dan memanfaatkan potensi - potensi alam yang bukan terbarukan namun tidak terbatas yaitu melalui ide, bakat dan kreativitas. Selain itu menurut (Kreatif, 2019),

Ekonomi kreatif adalah menciptakan sesuatu yang unik dan baru dengan menghasilkan nilai tambah yang berbasis kreativitas. Hal ini dapat diartikan bahwa ekonomi kreatif adalah suatu konsep yang dapat direalisasikan melalui penciptaan sesuatu yang baru dan unik dengan memanfaatkan kreativitas dan potensipotensi alam yang dapat terbarukan namun tidak terbatas dan semua itu ditunjang dengan pengetahuan, pengetahuan merupakan aspek yang paling penting dalam ekonomi kreatif menurut hasil penelitian (Hasan, 2018), semua itu diperlukan dukungan pemerintah desa dengan memperdayakan semua potensi-potensi yang ada di desa, pemberdayaan menjadi kunci pembangunan yang memfokuskan semua aspek baik aspek sumber daya manusia, material, fisik hingga aspek manajerial (Hartono dkk., 2010). Keberadaan ekonomi kreatif menjadi sesuatu yang istimewa di Indonesia, bagaimana tidak dengan adanya keberagaman yang dimiliki menjadi potensi yang sangat potensial untuk dapat dikembangkan terutama berkaitan dengan kearifan lokal yang ada di setiap daerah.

Kalimantan Barat merupakan salah satu daerah yang memiliki keberagaman kearifan lokal dengan potensipotensi alam yang layak dikembangkan namun belum dimaksimalkan dengan baik.

hal ini dibuktikan dengan sebaran data pelaku ekonomi kreatif di masing-masing daerah, berdasarkan data yang diambil dari badan ekonomi kreatif pelaku ekonomi kreatif Kabupaten Bengkayang tumbuh sebesar $0.74 \%$ dimana potensi ini belum banyak dikembangkan baik itu di bidang kuliner, kriya, pertanian yang bisa di sesuaikan dengan potensi yang ada di kabupaten Bengkayang artinya masih banyak potensi yang harus dimaksimalkan guna menumbuhkan usaha baru dan mengurangi angka kemiskinan.

Terutama di bidang pertanian hampir semua wilayah Kabupaten Bengkayang menjadikan pertanian sebagai sumber mengatasi masalah kemiskinan (Deffrinica, 
2019). Dalam membantu perkembangan ekonomi kreatif di daerah tersebut dengan melihat potensi yang ada di daerah sekitarnya, perlu adanya upaya-upaya untuk mendorong ekonomi kreatif yang tentunya mendorong pertumbuhan usaha baru di Kabupaten Bengkayang, bahwa perkembangan suatu hal ini tentu sejalan dengan Misi Badan Ekonomi Kreatif yaitu membangun ekosistem yang mampu 1. Mendorong pertumbuhan usaha baru ekonomi kreatif; 2. Meningkatkan nilai tambah produk kreatif dalam perekonomian nasional; 3 . Menghasilkan produk unggulan ekonomi kreatif yang dikenal dan digemari di pasar global.

Terwujudnya misi ini tentunya perlu keterlibatan pihak-pihak yang terlibat diantaranya ketersediaan sumber daya manusia yang ahli di bidangnya, adanya sumber permodalan, infrastruktur, hak kekayaan intelektual, regulasi dan kelembagaan yang menciptakan iklim usaha yang kondusif yang tentunya mendukung ekonomi kreatif semua ini tentunya didukung oleh riset dan pengembangan sebagai dasar untuk merumuskan kebijakan dan adanya perkembangan program dan kegiatan yang dilakukan untuk meningkatkan jumlah pelaku ekonomi kreatif terutama di Kabupaten Bengkayang.

Harapannya Ekonomi kreatif yang ada di Kabupaten Bengkayang dapat meningkatkan perekonomian masyarakat sekitarnya dan dapat membantu menanggulangi pengangguran khususnya di daerah pedesaan terutama di Desa Suka Maju kecamatan Sungai Betung yang terletak di Kabupaten Bengkayang, karena dengan berkembangnya desa dan kawasan pedesaan menjadi salah satu faktor penting dalam pembangunan suatu wilayah (Soleh, 2017), Jika dilihat potensi-potensi yang ada di kecamatan Sungai Betung sektor pertanian merupakan salah satu sektor yang menopang perekonomian di daerah tersebut (Yulita, 2019) namun belum dioptimalkan dengan baik hal ini terlihat dari belum adanya unit usaha yang dikelola oleh desa, seperti yang kita ketahui bahwa perkembangan suatu wilayah itu didukung oleh berkembangnya wilayah pedesaan.

Untuk itu perlu digali lebih jauh apa saja potensi desa yang dapat dimanfaatkan agar ekonomi kreatif yang ada di desa Suka maju dapat dijadikan sebagai acuan meningkatkan potensi desa, sehingga nantinya desa dapat mengelola unit usaha menjadi sumber pendapatan yang dapat dijadikan Badan usaha milik desa.

\section{RUANG LINGKUP}

Dalam penelitian ini permasalahan mencakup:

1. Apa saja potensi desa yang dapat menjadi peluang ekonomi kreatif di Desa Suka Maju

2. Faktor yang menjadi penghambat peluang ekonomi kreatif di Desa Suka Maju

\section{BAHAN DAN METODE}

Berikut pada tabel 1, gambaran pelaku usaha ekonomi kreatif yang ada di Provinsi Kalimantan Barat.
Tabel 1. Data Pelaku Usaha Ekonomi Kreatif Kalimantan Barat

\begin{tabular}{|l|l|c|}
\hline No & \multicolumn{1}{|c|}{ Kabupaten / kota } & Total \\
\hline 1. & Kabupaten Kubu Raya & $13.83 \%$ \\
\hline 2. & Kota Pontianak & $64.69 \%$ \\
\hline 3. & Kabupaten Mempawah & $3.21 \%$ \\
\hline 4. & Kota Singkawang & $7.16 \%$ \\
\hline 5. & Kabupaten Sambas & $3.70 \%$ \\
\hline 6. & Kabupaten Kapuas Hulu & $0.74 \%$ \\
\hline 7. & Kabupaten Melawi & $1.23 \%$ \\
\hline 8. & Kabupaten Ketapang & $2.22 \%$ \\
\hline 9. & Kabupaten Kayong Utara & $0.49 \%$ \\
\hline 10. & Kabupaten Sintang & $0.49 \%$ \\
\hline 11. & Kabupaten Sekadau & $0.49 \%$ \\
\hline 12. & Kabupeten Sanggau & $0.49 \%$ \\
\hline 13. & Kabupaten Bengkayang & $0.74 \%$ \\
\hline 14. & Kabupaten Landak & $0.49 \%$ \\
\hline
\end{tabular}

Sumber : badan Ekonomi Kreatif 2019

\subsection{Ekonomi Kreatif}

Menurut (Purnomo, 2016) ekonomi kreatif merupakan salah satu konsep ekonomi yang dapat direalisasikan secara berkelanjutan dengan memanfaatkan kreativitas yang dimiliki dan memanfaatkan potensi - potensi alam yang bukan terbarukan namun tidak terbatas yaitu melalui ide, bakat dan kreativitas. Selain itu menurut (Bekraf, 2015), ekonomi kreatif adalah menciptakan sesuatu yang unik dan baru dengan menghasilkan nilai tambah yang berbasis kreativitas, untuk itu badan ekonomi kreatif memfokuskan 16 subsektor diantaranya, aplikasi dan game developer, arsitektur, desain interior, desain komunikasi visual, desain produk, fashion, film, animasi \& video, fotografi, kriya, kuliner, musik, penerbitan, periklanan, seni pertunjukan, seni rupa, serta televisi dan radio.

Ekonomi kreatif adalah konsep yang dapat direalisasikan melalui penciptaan sesuatu yang baru dan unik dengan memanfaatkan kreativitas dan potensipotensi alam yang terbarukan namun tidak terbatas. Faktor penghambat ekonomi kreatif menurut Renstra Bekraf dalam (Netrawati; S.A, 2019) bahwa hambatan perkembangan ekonomi kreatif adalah sebagai berikut :

1. Perkembangan ekonomi kreatif belum optimal, model yang dijalankan ekonomi kreatif masih sederhana

2. Perkembangan kreasi ekonomi kreatif belum optimal

3. Kurangnya jangkauan pasar bagi produk dan jasa kreatif di dalam dan luar negeri

4. Perpajakan yang tinggi serta regulasi transaksi elektronik belum dijalankan dengan baik

5. Minimnya akses pembiayaan ekonomi kreatif disebabkan belum sesuai nya pembiayaan pelaku ekonomi di sektor ekonomi kreatif

6. Perkembangan sumber daya ekonomi kreatif belum optimal baik itu dari sumber daya alam maupun sumber daya manusia yang berkaitan dengan kesenjangan ketersediaan bahan baku dan pendidikan serta standarisasi yang belum baik. 
Berdasarkan penjelasan diatas dapat disimpulkan bahwa hambatan tersebut berkaitan dengan produk yang dihasilkan pelaku ekonomi kreatif belum optimal, kurangnya inovasi produk, regulasi transaksi yang belum optimal, pembiayaan ekonomi kreatif yang sulit bagi ekonomi kreatif serta rendahnya sumber daya manusia dan sumber daya alam terkait dengan pendidikan dan bahan baku yang mengalami kesenjangan.

\subsection{Potensi Desa}

Potensi desa adalah kemampuan yang berkaitan dengan daya, kekuatan, dan kesanggupan yang dimiliki oleh desa dan mempunyai kemungkinan peluang untuk dikembangkan dengan tujuan meningkatkan kesejahteraan masyarakat berkaitan dengan potensi fisik yaitu berupa tanah, air, iklim, lingkungan geografis, binatang ternak, dan sumber daya manusia, selain itu potensi non-fisik berkaitan dengan masyarakat dengan corak dan interaksi nya, lembaga-lembaga sosial, lembaga pendidikan, dan organisasi sosial desa, serta aparatur dan pamong desa (Soleh, 2017).

Potensi desa meliputi Potensi geografis, potensi sumber daya alam, potensi sumber daya manusia, ekonomi di perdesaan, potensi sosial dan budaya, potensi kelembagaan, sarana dan prasarana di desa, artinya potensi desa adalah potensi yang mempunyai peluang untuk dikembangkan berkaitan dengan potensi sumber daya alam, sumber daya manusia, ekonomi di pedesaan, dimana potensi ini jika dimanfaatkan dan dikembangkan oleh masyarakat dapat menjadi salah satu sumber baru atau alternatif yang membantu pertumbuhan wilayah dan berdampak pada unit usaha yang dapat dikembangkan oleh desa menjadi Badan Usaha Milik Desa (Kartika, 2013).

\subsection{Metode penelitian}

Penelitian ini menggunakan metode kualitatif dengan pendekatan Studi Kasus, menurut (Soeherman, 2019) Pendekatan ini dilakukan untuk meneliti sebuah fenomenologi atau kasus yang terjadi di dalam kelompok, organisasi maupun masyarakat luas secara lebih mendalam.

1. Penelitian ini tentunya membahas secara holistik semua hal yang terjadi, mulai dari akar permasalahan yang dihadapi oleh manusia dengan sesamanya, hingga manusia dengan lingkungan dan pada umumnya penelitian kualitatif dengan pendekatan studi kasus akan menawarkan rekomendasi atas semua permasalahan yang ditemukan. Penelitian ini berfokus pada masyarakat Desa Suka Maju, Yang menjadi sumber data adalah perangkat desa dan masyarakat Desa Suka Maju.

2. Teknik Pengumpulan Data, observasi, wawancara mendalam, studi dokumentasi, validitas data dengan triangulasi agar data yang dihasilkan tidak rancu maka perlu dilakukan teknik triangulasi.
3. Teknik analisis data

Menurut (Bonnie Soeherman, 2019) 3 langkah dalam melakukan interpretasi data kualitatif atau cerita hasil penelitian yaitu eksplorasi merupakan tahap awal yang dilakukan dengan membaca wacana atau urutan kejadian dalam transkrip untuk mendapat gambaran, kesan dan gambaran umum dari hasil wawancara tersebut, selanjutnya temuan-temuan ini akan di interpretasi/tafsir untuk membuat konstruksikonstruksi baru dan berusaha mengungkapkan hal-hal eksplisit atau implisit dalam wacana tersebut, artinya hasil wawancara baik itu berupa rekaman atau pun di tulisan atau di deskripsi agar dapat ditemukan maknamakna yang jelas dalam penelitian tersebut.

Kemudian tahap selanjutnya adalah tahap kontekstualisasi, di sini peneliti meresapi dan memaknai teks sesuai konteks sosial penelitian berdasarkan hasil wawancara yang dilakukan oleh peneliti. Berikut Gambar 1. tahapan alat analisis yang dilakukan :

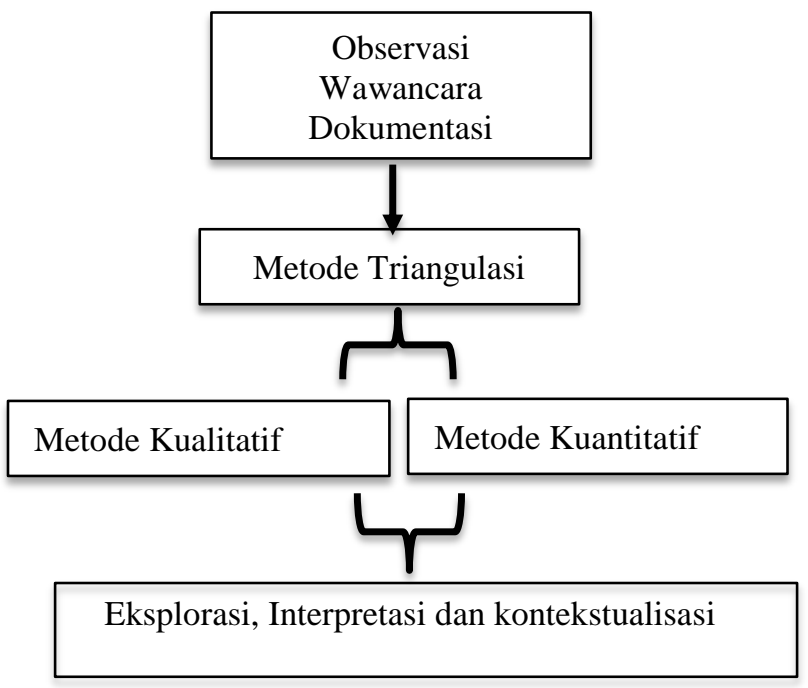

\section{Gambar 1. Tahapan Alat Analisis}

\section{PEMBAHASAN}

Berikut disajikan hasil dari penelitian ini

\subsection{Potensi Desa Suka Maju}

Pemerintah saat memberikan wewenang kepada setiap desa untuk dapat mengelola wilayah, ekonomi dan masyarakat. Semua itu tertuang dalam undang-undang desa, dengan adanya wewenang tersebut tentunya banyak cara yang dilakukan oleh desa untuk dapat mengembangkan ekonomi perdesaan dengan memanfaatkan potensi desa, hal ini juga berlaku di Desa Suka Maju kecamatan Sungai Betung berdasarkan hasil penelitian yang dilakukan ada beberapa potensi-potensi desa yang saat ini belum dikembangkan dan dimanfaatkan oleh desa, luasnya cakupan desa yang terdiri dari delapan dusun diantaranya dusun Sungai Betung Papak, Melikar Sungai Mao, Kayu Abak’ng, 
dusun Kawan, dusun Semidang dan Dusun Semunte setiap dusun memiliki potensi -potensi yang dapat dikembangkan dan dapat dimanfaatkan guna menunjang ekonomi masyarakat serta memberi nilai tambah dan usaha bagi desa sehingga terdapat sumber ekonomi baru bagi masyarakat setempat

Adapun potensi desa Suka Maju berdasarkan potensi yang dihasilkan oleh setiap dusun adalah sebagai berikut, potensi desa yang sangat menonjol saat ini lebih pada hasil pertanian. Pembukaan lahan untuk menanam padi di sawah maupun di ladang, hasilnya akan menjadi beras dan padi yang dapat mereka konsumsi sendiri, dan dijual untuk memenuhi kebutuhan rumah tangga dan dana Pendidikan anak.

Hasil potensi lainnya adalah sawit dan jagung, biasanya jagung yang mereka hasilkan itu tidak diolah namun langsung dijual, kurangnya pengetahuan masyarakat terhadap pengolahan jagung karena kurangnya pengetahuan mereka tentang pengolahan serta belum ada tenaga pendamping yang terampil dalam mendampingi mereka khususnya untuk mengolah jagung menjadi sebuah produk, produk olahan jagung biasanya memanfaatkan teknologi, dengan begitu menambah nilai komoditas dari jagung.

Selain itu peran teknologi berkaitan dengan memanfaatkan varietas produk unggul jagung berpotensi menghasilkan panen yang tinggi, perbaikan cara membudidayakan jagung, memanfaatkan mesin pengering serta memperhatikan lantai untuk menjemur dan gudang untuk menyimpan hasil panen, serta modal yang mendukung menjadi suatu hal yang dapat meningkatkan petani jagung (Witjaksono, 2017).

Di desa Suka Maju jagung dimanfaatkan menjadi pakan ternak sementara dengan memanfaatkan teknologi jagung dapat diolah menjadi corn-flake, popcorn, tepung jagung, minyak jagung (Maflahah, 2010), kurangnya informasi dan rendahnya sumber daya manusia menjadi salah satu faktor yang menyebabkan jagung di desa tersebut belum dimaksimalkan menjadi suatu produk yang bernilai jual ekonomis.

Selain itu potensi yang ada di desa Suka Maju adalah potensi karet, hampir semua dusun yang ada di desa tersebut memiliki karet yang diolah dengan cara disadap dan diambil karetnya, turunnya harga karet menyebabkan masyarakat di Desa Suka Maju sudah jarang memanfaatkan karet sebagai sumber penghasilan, namun di sisi lain masih banyak masyarakat yang menggantungkan hidupnya dari hasil karet. Menurunnya harga karet berdampak pada penghasilan yang di peroleh petani karet, penurunan daya beli hingga kemampuan investasi yang terbatas hingga pengalihan fungsi lahan karet (Syarifa dkk, 2016), Potensi air bersih yang belum dikelola dengan baik oleh desa. Desa Suka Maju ada dua dusun yang mendapatkan sumber air bersih yaitu dusun Sungai Betung dan Dusun Kayu Abak'ng dari pemerintah pusat melalui program PNPM dan Pamsimas, namun kelemahannya ada pada pengelolaan air bersih yang belum maksimal sehingga desa belum bisa mengelola menjadi badan usaha milik desa.

Pengelolaan air bersih yang baik berkaitan dengan pemeliharaan sumber air dan adanya perubahan pola perilaku masyarakat terhadap kesadaran hidup bersih dan sehat, adanya badan pengelolaan yang bertanggungjawab dan mampu mengelola sarana air bersih yang dapat ditunjuk oleh desa dan di SK sehingga badan yang ditunjuk tersebut menjadi organisasi yang sah baik di masyarakat kemudian tujuan dan fungsi pengelola juga harus dilampirkan sehingga badan tersebut akan jelas fungsi dan tugas pokoknya sebagai pengelola air bersih (Nengsi, 2019).

Selain itu potensi buah kenari yang dimiliki hampir oleh setiap dusun hanya saja buah tersebut musiman tidak setiap saat berbuah. Kurangnya pengetahuan dalam mengolah buah kenari membuat masyarakat langsung menjual dalam jumlah banyak. Mereka lebih memilih menjual buah ini secara langsung kepada pihak pengepul, penjualan buah kenari juga dilakukan hingga ke malaysia yaitu di Serikin, namun dalam segi pengolahan baik itu dari segi inovasi produk dimana buah kenari dapat dimanfaatkan menjadi biskuit dengan mencampurkan pati jagung menghasilkan produk bernilai ekonomis (Makanoneng, dkk, 2017) dan semua itu didukung teknologi serta kemampuan sumber daya manusia.

Potensi alam yang sedang dalam tahap perencanaan untuk dapat dikembangkan menjadi wisata alam yang berada di Dusun Semidang. Hal ini dapat diartikan bahwa saat ini banyak wilayah di Indonesia memanfaatkan potensi alam sebagai salah satu potensi yang dapat mengembangkan wilayahnya dengan pengelolaan yang baik potensi ini menjadi salah satu bentuk usaha milik desa yang dapat mendorong pendapatan desa, potensi desa menjadi sumber ekonomi kreatif, dimana dalam menjalankan pembangunan dan dapat menciptakan iklim ekonomi melalui pemanfaatan ide, mengamati, meniru, dan modifikasi suatu produk atau karya sehingga menjadi sebuah produk yang baru dan terbarukan, bukan hanya produknya saja yang baru tetapi melalui proses, cara dan sistemnya adalah sesuatu yang bersifat inovatif (Ridwan \& Surya, 2018).

Pembangunan potensi alam diperlukan inovasi yang tinggi dalam mengelola dan membangun wisata alam agar dapat berkembang dan dikenal oleh masyarakat luas, desa mendapatkan perhatian dari pemerintah pusat melalui anggaran desa yang di luncurkan oleh pemerintah pusat guna membangun pedesaan, pembangunan yang dijalankan bukan hanya digunakan untuk membangun fisik semata, namun diharapkan dapat membangun ekonomi desa yang berdampak pada kesejahteraan masyarakat dan semua itu dapat ditunjang melalui pelatihan-pelatihan yang dapat meningkatkan sumber daya manusianya dengan disesuaikan dengan kebutuhan dan peluang yang ada di desa tersebut sehingga berdampak pada desa mandiri. Strategi yang dilakukan dalam mengembangkan desa wisata terletak 
pada sumber daya manusia yang dengan sadar membentuk Pokdarwis (kelompok sadar wisata) sebagai ujung tombak dalam menggerakan masyarakat agar dapat mempunyai peran dalam mendukung pembangunan wisata di daerah tersebut dan bertanggungjawab menciptakan kondisi yang kondusif sehingga minat dalam berkunjung tinggi semua itu akan memberikan dampak bagi desa dari segi pendapatan maupun lapangan pekerjaan sehingga kualitas kehidupan akan semakin baik.

Potensi emas yang dimiliki oleh setiap dusun, naiknya harga emas beberapa bulan belakang ini menyebabkan masyarakat beralih profesi menjadi pendulang emas namun sayangnya pertambangan ini masih bersifat ilegal dan dilakukan secara tradisional. Perlu diketahui bahwa dalam menjalankan kegiatan ini terdapat dua dampak sosial yang dirasakan masyarakat (Trisna, 2017) yaitu dampak positifnya dengan adanya aktivitas pendulang emas masyarakat mendapatkan kesempatan dalam bekerja, dari segi pendapatan dapat meningkat karena mereka dapat menjadi buruh penambang, angka pengangguran menurun di desa setempat, munculnya jenis usaha baru di sekitar lokasi pertambangan tersebut berupa warung makan. Kemudian dampak negatifnya lingkungan menjadi rusak, pencemaran air yang tidak bisa dimanfaatkan oleh masyarakat sekitar desa sehingga mereka akan mencari sumber air yang baru, perjudian dan perselingkuhan.

Dari segi anyaman yang dibuat masih bersifat tradisional dan masih bergantung pada model-model yang turun temurun mereka dapat dari orang tua mereka, untuk itu perlu dilakukan langkah-langkah strategis guna memberikan pengetahuan yang baru bagi mereka yakni pendidikan informal yang diimplementasikan melalui anyaman bambu sebagai sarana dalam mengentaskan permasalahan yang ada di masyarakat berkaitan dengan kemiskinan dan semua itu arus didukung oleh pemerintah daerah dan desa setempat (Apriliani, 2018). Dengan adanya pendidikan informal mereka mendapatkan pengetahuan baru tentang bentuk anyaman, pola anyaman serta produk-produk yang dihasilkan dapat di inovasi sehingga produk tersebut menarik dan disenangi oleh masyarakat luas.

\subsection{Peluang Ekonomi Kreatif Di Desa Suka Maju}

Berdasarkan hasil penelitian yang dilakukan bahwa potensi anyaman bambu menjadi peluang ekonomi kreatif bagi desa Suka Maju, hal ini karena masih banyak ibu-ibu dan bapak-bapak memiliki keahlian dalam menganyam dan hampir di semua dusun memiliki penganyam bambu, hal ini juga didukung oleh potensi alam berupa banyaknya bambu-bambu yang masih tersedia di hutan selain itu para penganyam juga memadukan anyaman bambu dengan rotan.

Namun hasil anyaman bambu masih bersifat tradisional karena para penganyam hanya menganyam produk kebutuhan para petani yang ada di sekitar desa yaitu berupa rancang, sikup, raga dan penampi. Harga produk juga dipatok sesuai dengan kerumitan anyaman yang dibuat.

Rendahnya kualitas produk dan kurangnya inovasi pada produk yang mereka buat menjadikan anyaman ini hanya dikenal di sekitar Desa saja belum ada pelatihan dalam meningkatkan keterampilan para penganyam bambu hal ini.

Ibu-ibu penganyam juga memanfaatkan kegiatan anyaman sebagai salah satu kegiatan untuk memanfaatkan waktu luang. Peran wanita sebagai penunjang ekonomi keluarga saat ini sangat nyata tidak hanya di desa Suka Maju namun juga di seluruh Indonesia (Deffrinica, 2020). Namun di samping itu anyaman bambu juga mempunyai potensi untuk dapat dikembangkan menjadi ekonomi kreatif di desa Suka Maju dimana seperti yang disampaikan oleh (Saksono, 2012) bahwa ekonomi kreatif dapat menjadi kontribusi ekonomi bagi desa karena jika dikelola dengan baik maka akan memberikan lapangan pekerjaan baru bagi masyarakat yang menganggur, kemudian dapat meningkatkan pendapatan desa, selain itu menjadikan iklim bisnis bagi sektor lain yaitu pemasaran, jangkauan pemasaran produk menjadikan produk tersebut lebih dikenal di luar wilayah.

Tujuan lainnya menjadi sumber ekonomi terbarukan karena ilmu pengetahuan baru yang dapat ditingkatkan melalui kreativitas karena akan ada ide-ide baru yang diciptakan, selain itu dampak sosial nya masyarakat pemerataan kesejahteraan sehingga berdampak pada peningkatan kualitas hidup, selain itu meningkatkan citra dan identitas bangsa hal ini tentunya menjadikan meningkatnya nilai lokal karena produk yang dihasilkan dapat dikenal oleh masyarakat luar.

Perlu adanya kegiatan brainstorming bagi masyarakat setempat guna memberikan pengetahuan baru untuk meningkatkan kreativitas mereka maka diperlukan kerja sama masyarakat setempat dan perangkat desa kegiatan ini dimulai dengan tahap sosialisasi, masyarakat diajak untuk mengetahui apa saja manfaat bambu dan bagaimana teknik menganyam, setelah itu akan dibentuk kelompok masyarakat yang terdiri dari para penganyam untuk membentuk satu organisasi dimana dalam organisasi ini nantinya mereka akan mengetahui apa fungsi dan tugas pokok mereka. Dimana dalam organisasi ini mereka diajarkan untuk saling mendukung dan bekerja sama, setelah itu dilakukan tahap penentuan jadwal pelaksanaan dan tempat kegiatan dalam hal ini perlu dipersiapkan bahan yang diperlukan, pada saat yang sudah ditentukan masyarakat yang terdiri dari para penganyam ini dikumpulkan di suatu tempat dan diajarkan teknik menganyam dan mengolah bambu. Setelah itu akan dilanjutkan dengan mendampingi kelompok ini untuk melakukan pemasaran dan penjualan siapa saja yang akan menjadi target konsumennya, hal selanjutnya yang akan dijalankan adalah pendampingan dalam mengelola keuangan, tentunya semua ini dapat berjalan dengan adanya kerja sama institusi, pemerintah 
daerah dan pemerintah desa sebagai tuan rumah terselenggaranya kegiatan ini.

\subsection{Faktor Penghambat Perkembangan Peluang Ekonomi Kreatif Adalah}

1. Kurangnya pengetahuan berkaitan dengan rendahnya sumber daya manusia, Hal ini berkaitan dengan kurangnya informasi yang diperoleh karena dari segi pendidikan dan keterampilan yang jauh sehingga berdampak pada produk yang dihasilkan serta manajemen pengelolaan usaha anyaman bambu tersebut. Pendidikan menjadi faktor pendukung dalam meningkatkan keterampilan hal ini disampaikan (Vuspitasari \& Ewid, 2020) bahwa melalui pendidikan masyarakat dapat menghapus ketertinggalan mereka dengan mendapatkan pengetahuan baru mereka akan menjadikan sumber inspirasi yang dapat dikembangkan baik dalam usaha maupun dalam kehidupan mereka sehari-hari.

2. Kurangnya kesadaran dalam memanfaatkan potensi desa. Potensi desa Suka Maju sangat banyak hal ini dapat dilihat dari hasil pembahasan yang sudah dilakukan diatas, namun potensi-potensi tersebut belum dimaksimalkan karena keterbatasan pengetahuan masyarakat akan pentingnya memanfaatkan. potensi desa guna membangun masyarakat desa, perlu adanya pembinaan dari desa agar masyarakat mendapatkan pengetahuan baru sehingga ide-ide tersebut akan timbul dan menjadi sumber baru bagi kemajuan desa. Salah satunya adalah anyaman bambu, saat ini yang menjadi kendala terhambat nya perkembangan anyaman bambu di daerah karena rendahnya peran pemerintah daerah dalam mendukung potensi anyaman bambu dikarenakan pangsa pasar yang terbatas, sarana prasarana dari daerah juga masih rendah. Namun pada kenyataan potensi anyaman sangat diminati oleh masyarakat luar negeri (Razak \& Elyta, 2017).

3. Masyarakat terbiasa melakukan semua hal namun tidak difokuskan. Masyarakat terbiasa melakukan semua hal berkaitan dengan kebiasaan yang dilakukan oleh masyarakat setempat dalam hal ini masyarakat senang melakukan semua hal misalnya mereka terbiasa memelihara ternak ayam dan ternak babi namun tidak ada difokuskan untuk dikembangkan, begitu pula dengan pertanian misalnya mereka menanam jagung mereka juga menanam padi hal ini membuat terpecahnya konsentrasi ketika menjalankan kegiatan tersebut sehingga tidak fokus dan berdampak pada hasil yang mereka peroleh

4. Kurangnya peran desa dalam membina para penganyam bambu. Peran pemerintah dalam mengembangkan suatu wilayah sudah bukan hal yang rahasia lagi, terlebih pemerintah desa, pentingnya pembinaan dalam suatu kegiatan di desa terutama dalam peningkatan keterampilan potensi desa khususnya anyaman bambu

5. Kurangnya modal

Kurangnya informasi serta tidak adanya legalitas dari anyaman yang dimiliki menjadi kendala dalam mengembangkan produk anyaman bambu, hal ini berkaitan dengan kurangnya peran desa dalam membantu membina para penganyam bambu untuk dapat mengetahui informasi tentang ketersediaan modal pinjaman yang disediakan layanan bank melalui pinjaman kredit usaha rakyat.

\section{KESIMPULAN}

Potensi desa Suka Maju berkaitan dengan hasil pertanian dan perkebunan dimana masyarakat lebih banyak mengolah lahan untuk menanam padi di sawah maupun di ladang, selain itu jagung, karet, buah kenari, emas , karet dan sawit yang menjadi potensi ekonomi kreatif adalah anyaman bambu namun anyaman ini tidak berkembang dengan baik dan belum dikenal secara luas karena produk yang dihasilkan kurang inovatif karena produk yang dihasilkan berupa produk yang biasa dipesan oleh masyarakat sekitar berkaitan dengan perlengkapan rumah tangga dan pertanian yaitu, rancang, penjarangan, penampi dan bakul.

Faktor -faktor penghambat peluang perkembangan ekonomi kreatif, Kurangnya pengetahuan berkaitan dengan rendahnya sumber daya manusia, Kurangnya kesadaran dalam memanfaatkan potensi desa, Masyarakat terbiasa melakukan semua hal namun tidak difokuskan, Kurangnya peran desa dalam membina para penganyam bambu, Kurangnya modal

\section{SARAN}

Perkembangan ekonomi kreatif suatu desa didukung oleh pemerintah setempat dan kerja sama masyarakat desa perlu adanya dibentuk kelompok penganyam bambu bagi masyarakat desa Suka Maju agar mereka dapat dibina sehingga pemantauan, peningkatan keterampilan dapat dilakukan sehingga penganyam bambu juga akan dapat melakukan inovasi dari produk anyaman yang mereka produksi. Perlu adanya pendampingan dalam meningkatkan legalitas usaha melalui pembuatan ijin usaha sehingga mempermudah masyarakat dalam memenuhi syarat untuk melakukan peminjaman modal guna mengembangkan usaha mereka. Perlu adanya pendampingan dalam pembentukan Pokdarwis guna menggerakan masyarakat yang sadar akan potensi alam yang dapat dimanfaatkan sebagai usaha desa yang dapat berdampak pada kesejahteraan masyarakat. 


\section{DAFTAR PUSTAKA}

Soeherman, B. 2019. Fun Research Penelitian Kualitatif dengan Design Thinking. PT. Elex Media Komputindo.

BPS Bengkayang. 2019. Statistik Kesejahteraan Rakyat Kabupaten Bengkayang 2019. https//bengkayangkab.bps.go.id

Deffrinica, D., Vuspirasari, B. K., \& Hapsari, V. R. 2020. PENGUATAN KETAHANAN PANGAN DALAM MENINGKATKAN EKONOMI RUMAH TANGGA PETANI DALAM MENGENTASKAN KEMISKINAN. Business, Economics and Entrepreneurship, 2(1), 48-54.

Hartono, D. U., \& Mulyanto, E. 2010. Electronic Government Pemberdayaan Pemerintahan dan Potensi Desa Berbasis Web. Jurnal Teknologi Informasi, 6(1), 9-21.

Hasan, M. 2018. Pembinaan Ekonomi Kreatif Dalam Perspektif Pendidikan Ekonomi. JEKPEND: Jurnal Ekonomi Dan Pendidikan, 1(1), 81. https://doi.org/10.26858/jekpend.v1i1.5063

Kartika, R.S. 2013. Peluang Mengembangkan Kewirausahaan Desa Berbasis Potensi Desa (Studi Deskriptif di Desa Karang Rejo Kecamatan Negeri Katon Kabupaten Pesawaran, Kampung Suka Jawa Kecamatan Bumi Ratu Kabupaten Lampung Tengah dan Desa Sidoasri Kecamatan Candi Puro Kabupate. Jurnal Bina Praja, 05(04), 281-300. https://doi.org/10.21787/jbp.05.2013.281-300

Kreatif, B. E. 2019. Informasi sebaran pelaku ekonomi kreatif.

Kreatif, B. E. 2017. Rencana Strategis Badan Ekonomi Kreatif 2015-2019.

Maflahah, I. 2010. Analisis Proses Pembuatan Pati Jagung ( Maizena ). Embryo, 7(1), 40-45.

Makanoneng, V. S., Nurali, E. J. N., \& Djarkasi, G. S. S. 2017. Pengembangan Biskuit Kenari (Canarium Indicum L) Berbahan Baku Tepung Sagu Baruk (Arenga Microcarpa). Cocos, 1(2).

Nengsi, S. 2019. Analisis Keberlangsung Program Penyediaan Air Minum Dan Sanitasi Berbasis Masyarakat (Pasca PAMSIMAS) Di Desa Lilli Kecamatan Matangnga Kabupaten Polewali Mandar. J-KESMAS: Jurnal Kesehatan Masyarakat, 4(1), 33. https://doi.org/10.35329/jkesmas.v4i1.233

Netrawati, I. G. A., Suastina, I. G. P., \& Ali, J. 2019. Hambatan Dalam Pengembangan Ekonomi Kreatif di Kabupaten Lombok Tengah (Studi Kasus Pada Perajin Kain Tenun Tradisional Dusun Sade). Jurnal Media Bina Ilmiah, 14(4)

Apriliani, R. P. A. 2018. Pengentasan Kemiskinan Di Desa Talok Melalui Pendidikan Non Formal Berbasis Anyaman Bambu Dengan Metode Pembangunan Berkelanjutan Pasal 7 UU No. 13 Tahun 2011 Menuju Sustainable Development Goals (Sdgs) Di Indonesia 2045. Lex Scientia Law Review, 2(1), 31-46.
Purnomo, R. A. 2016. Ekonomi Kreatif Pilar Pembangunan Indonesia. Ziyad Visi Media.

Razak, A., \& Elyta, 2017. Faktor Penghambat Kerajinan Anyaman Tangan Di Perbatasan Sajingan Besar Dalam Menghadapi Masyarakat Ekonomi Asean. Sosiohumaniora, 19(3), 213-217. https://doi.org/10.24198/sosiohumaniora.v19i3.1340 3

Ridwan, R., \& Surya, C. 2018. Pemberdayaan masyarakat desa dalam mengembangkan ekonomi kreatif di desa citengah kabupaten sumedang. Jurnal Riset Akuntansi Kontemporer, 10(1), 28-33.

Saksono, H. 2012. Ekonomi Kreatif: Talenta Baru Pemicu Daya Saing Daerah. Jurnal Bina Praja, 04(02), 93-104. https://doi.org/10.21787/jbp.04.2012.93-104

Soleh, A. 2017. Strategi Pengembangan Potensi Desa. Jurnal Sungkai, 5(1), 32-52.

Syarifa, L. F., Agustina, D. S., Nancy, C., \& Supriadi, M. 2016. Dampak rendahnya harga karet terhadap kondisi sosial ekonomi petani karet di Sumatera Selatan. Indonesian Journal of Natural Rubber Research,34(1), 119-126. Trisna, A. (2017). Dampak sosial penambangan emas tanpa izin (PETI) di Desa Sungai Sorik Kecamatan Kuantan Hilir Seberang Kabupaten Kuantan Singingi. Jurnal Online Mahasiswa, 4(2), 1-13.

Vuspitasari, B. K., \& Ewid, A. 2020. Peran Kearifan Lokal Kuma Dalam Mendukung Ekonomi Keluarga Perempuan Dayak Banyadu. Sosiohumaniora, 22(1). https://doi.org/10.24198/sosiohumaniora.v22i1.2407 8

Witjaksono, J. 2017. The Assessment of Value Chain and Value Added Analysis of Maize (Case Study in Konawe District, Southeast Sulawesi Province). Jurnal Ilmu Pertanian Indonesia, 22(3), 156-162. https://doi.org/10.18343/jipi.22.3.156

Yulita, Y., \& Gunawan, C. I. (2019). Model Strategi Manajemen Kebijakan Publik Sektor Pasar Tradisional Untuk Peningkatan Pendapatan Asli Daerah Di Kabupaten Bengkayang Kalimantan Barat. Referensi: Jurnal Ilmu Manajemen Dan Akuntansi, 7(1), 37-45. 